\title{
İyileşmeyen Pnömoni ile Başvuran Bir Atipik Kawasaki Hastalığı Olgusu
}

\author{
A Case of Atypical Kawasaki Disease Presenting with Unresolving Pneumonia
}

\section{Mustafa ÇAKAN ${ }^{1}$, Nuray Aktay AYAZ ${ }^{1}$, Gonca KESKİNDEMİRCI ${ }^{2}$ Hamide Sevinç GENÇ ${ }^{2}$, Helen BORNAUN ${ }^{3}$}

1. Kanuni Sultan Süleyman Eğitim ve Araştırma Hastanesi, Çocuk Romatoloji Kliniği, İstanbul

2. Kanuni Sultan Süleyman Eğitim ve Araştırma Hastanesi, Çocuk Sağığı ve Hastalıkları Kliniği, Istanbul

3. Kanuni Sultan Süleyman Eğitim ve Araştırma Hastanesi, Çocuk Kardiyoloji Kliniği, İstanbul

Bu olgu sunumu XV. Ulusal Romatoloji Kongresinde (29 Ekim - 2 Kasım 2014 / Antalya) bildiri olarak sunulmuştur.

$\ddot{O Z E T}$

Giriş: Kawasaki hastalığı çocukluk çağında sık gözlenen, nedeni bilinmeyen sistemik bir vaskülittir. Karakteristik bulguları ateş, polimorfik döküntü, konjonktivit, oral mukoza ve ekstremite değişiklikleri ve servikal lenfadenopatidir. En önemli morbidite ve mortalite nedeni kardiyak tutulumdur. Başlangıç döneminde öksürük ve burun akıntısı ile bulgu veren üst solunum yolu tutulumu göreceli olarak sik görülmesine karşın pnömoni şeklinde akciğer tutulumu ile seyretmesi son derece nadirdir.

Olgu: On altı aylik erkek hasta uzamlş ateş ve iyileşmeyen pnömoni nedeniyle kliniğimize sevk edildi. Akciğer grafisinde konsolidasyon saptanan olguda takipte Kawasaki hastalığı tanısı konuldu. Antibiyotik tedavisi ile klinik ve laboratuar bulgularında düzelme olmayan olguda tek doz intravenöz immünoglobulin (2 gr/kg) uygulanması sonucu klinik ve röntgen bulgularında düzelme gözlendi.

Sonuç: Uzamış ateş, antibiyotik tedavisi ile düzelmeyen pnömoni ve belirgin akut faz yanitı olan olgularda Kawasaki hastalığı ayırıcı tanıda düşünülmelidir.

Anahtar Kelimeler: çocuk; kawasaki hastalığl; pnömoni

\section{ABSTRACT}

Introduction: Kawasaki disease is a systemic vasculitis with unknown etiology that is common among children. Characteristic findings are fever, polymorphic rash, conjunctivitis, oral mucosa and extremity changes and cervical lymphadenopathy. The most important cause of morbidity and mortality is cardiac involvement. At the early stages of the disease, upper airway tract symptoms like coryza and cough are common. But lung parenchyme involvement as pneumonia is extremely rare.

Case: A 16-months-old boy was admitted to our clinic due to prolonged fever and unresolving pneumonia. Consolidation was observed on the chest X-ray. On the follow up, the child was diagnosed as having Kawasaki disease. Clinical and laboratory remission could not be achieved by antibiotic treatment. Clinical and chest X-ray findings were normalized after one dose intravenous immunoglobulin infusion $(2 \mathrm{gr} / \mathrm{kg})$.

Conclusion: In patients with prolonged fever, unresolving pneumonia with antibiotic treatment and high acute phase reactants, Kawasaki disease should be in differential diagnosis.

Keywords: child; kawasaki disease; pneumonia

\section{İletişim:}

Sorumlu Yazar: Mustafa CCAKAN

Adres: Kanuni Sultan Süleyman Eğt. ve Arş. Hastanesi Turgut Özal Bulvarı No:1 Küçükçekmece / İstanbul Tel: +90 (212) 4041500

E-Posta: mustafacakan@hotmail.com

Makale Geliş: 03.05.2016

Makale Kabul: 23.06.2016

DOI: http://dx.doi.org/10.16948/zktipb.237240 


\section{GİRİŞ}

Kawasaki hastalığı $(\mathrm{KH})$ çocukluk çă̆ına özgü, en sik olarak 6 ay - 5 yaș arasında gözlenen sistemik bir vaskülittir (1). Siklıkla kendi kendini sınırlayan bir tablo çizmesine rağmen en önemli morbidite ve mortalite koroner arter tutulumu nedeniyle olmaktadır. İlk olarak 1967 yılında tanımlanan hastalığın etiyopatogenezi üzerine yoğun araştırmalar yapılmasına rağmen halen hastalığın nedeni saptanamamıștır $(2,3)$. Özgül bir laboratuar testi olmadığı için tanı klinik kriterlere dayanılarak konulur. KH tanı kriterleri 5 günü geçen ateş yanında, bilateral pürülan olmayan konjonktivit, yaygın orofaringeal hiperemi, çilek dili, dudaklarda kızarıklık ve çatlama şeklinde orofarenks değişiklikleri, tek taraflı servikal lenfadenopati, polimorfik döküntü ve akut dönemde el ve ayaklarda eritem veya ödem ile subakut dönemde periungual soyulma şeklinde olan ekstremite değişiklerinin bir arada olmasıdır $(4,5)$. Hastalığın başlangıç döneminde burun akıntısı ve öksürük şeklinde bulgu veren üst solunum yolu tutulumu $\% 35$ oranında görülmesine rağmen pnömoni şeklinde akciğer parenkimi tutulumu vaka sunumları şeklinde mevcuttur (6). Yazımızda uzamış ateş ve iyileşmeyen pnömoni nedeniyle izlenen, takibinde KH tanısı konulan ve intravenöz immünoglobulin (IVIIG) tedavisi sonrası klinik, laboratuar ve görüntüleme bulgularında düzelme gözlenen olgu sunulmuştur.

\section{OLGU}

On altı aylık erkek hasta üc gündür var olan ateş, burun akıntısı ve öksürük şikayeti ile başvurduğu hastanede üst solunum yolu enfeksiyonu tanısı konularak oral antibiyotik tedavisi başlanmış. İki gün sonraki kontrolde şikayetlerinde gerileme olmaması üzerine hastaneye yatırılan olgunun kan sayımında lökosit sayısı
$16.500 / \mathrm{mm}^{3}$, hemoglobin $10.3 \mathrm{~g} / \mathrm{dl}$, trombosit

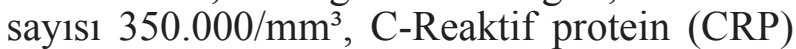
$26 \mathrm{mg} / \mathrm{L}$, eritrosit sedimentasyon h1zı (ESH) $30 \mathrm{~mm} / \mathrm{saat}$ saptanmış. Çekilen ön-arka akciğer grafisinde sağ akciğer orta ve alt lobta parakardiyak infiltrasyon saptanması üzerine (Şekil 1a) pnömoni tanısıyla intravenöz seftriakson tedavisi başlanmış. Dört gün süre ile uygulanan tedaviye rağmen ateşi devam ettiği için hastanemize sevk edilen olgunun muayenesinde sağ akciğer orta ve alt loblarda krepitasyonlar ve bilateral hafif konjonktival hiperemi mevcuttu.

Antibiyotik tedavisine devam edilen olguda uzamış ve antipiretiklere dirençli ateş ve bilateral konjonktival hiperemi olması nedeniyle ayırıcı tanıda inkomplet KH'da yer aldığı için yapılan ekokardiyografide koroner arterlerde dilatasyon saptanmadi.

Hastalığın on ikinci, hastanemize yatıșının üçüncü gününde ateși devam eden hastanın perineal döküntü, el ve ayak sırtında ödem, çilek dili ve dudaklarda çatlama tarzında tipik $\mathrm{KH}$ bulguları oluşmaya başladı. Tam kan sayımında trombosit sayıs $915.000 / \mathrm{mm}^{3}$, CRP değeri 44 $\mathrm{mg} / \mathrm{L}$, ESH değeri $65 \mathrm{~mm} / \mathrm{saat}$ saptandı. İkinci ekokardiyografik incelemede sağ koroner arterde $4 \mathrm{~mm}$ (Z skor: 6.45), sol koroner arterde 4.5 mm ektazi (Z skor: 5.50) saptand1. KH tanıs1 konularak $2 \mathrm{gr} / \mathrm{kg}$ İVİG ve $80 \mathrm{mg} / \mathrm{kg} /$ gün salisilat tedavisi başlandı. Akciğer grafisinde infiltratif görünümde düzelme saptanmayan ve kan kültüründe üreme olmayan olgunun akciğer bulguları primer $\mathrm{KH}$ pnömonisi kabul edilerek antibiyotik tedavisi kesildi. Tek doz IVİG tedavisi sonrası ateși düșen hastanın klinik bulgularında belirgin düzelme oldu. İVİG tedavisinden bir hafta sonra çekilen akciğer grafisinde pnömonik infiltrasyonun düzeldiği gözlendi (Şekil 1b). İkinci haftada CRP değeri $3 \mathrm{mg} / \mathrm{L}$ saptanan

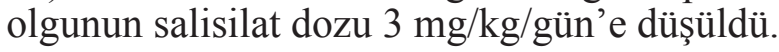

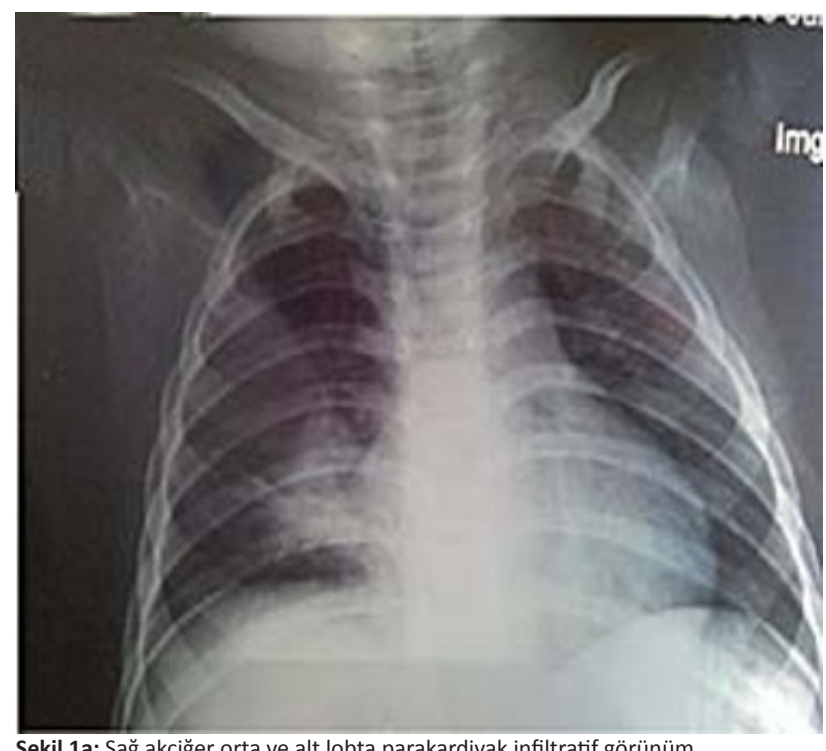

Şekil 1a: Sağ akciğer orta ve alt lobta parakardiyak infiltratif görünüm..

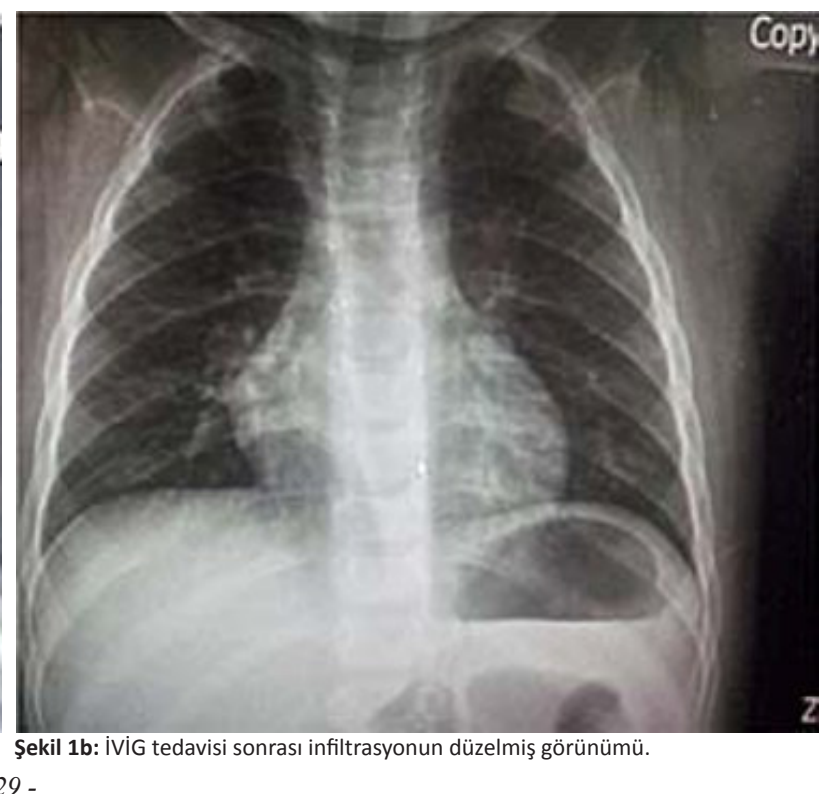


Üçüncü haftada lökosit sayısı 5700/ $\mathrm{mm}^{3}$, hemoglobin $10.5 \mathrm{~g} / \mathrm{dl}$, trombosit say1s1 532.000/ $\mathrm{mm}^{3}$, CRP $2 \mathrm{mg} / \mathrm{L}, \mathrm{ESH} 8 \mathrm{~mm} /$ saat saptand. Birinci ayında çekilen ekokardiyografide koroner arterlerde ektazi saptanmadi. Salisilat tedavisi ikinci ayında kesildi. Hastamız 2 yıldır komplikasyonsuz takip edilmektedir.

\section{TARTIŞMA}

KH çocukluk çağında göreceli olarak s1k gözlenen sistemik bir vaskülittir. İlk tanımlanmasının üzerinden yaklaşık 50 yıl geçmiş olmasına rağmen halen etiyolojisi aydınlatılamamıştır. Çocuk yaşta sık görülmesi, 3 ayın altında ve erişkinlerde çok nadir görülmesi, kendi kendini sınırlandıran bir tablo izlemesi, yıl içinde belirli dönemlerde daha sık rastlanması nedeniyle hastalığ 1 tetikleyen faktörün süperantijen üretebilen enfeksiyöz bir ajan olduğu hipotezi üzerinde yoğunlaşılmaktadır $(7,8)$. Tanı koydurucu spesifik bir laboratuar testi olmadığ 1 için hastalığın tanısı klinik kriterlere dayanılarak konulur. Klasik (komplet) KH tanı kriterleri 5 günü geçen ateş yanında, bilateral pürülan olmayan konjonktivit, orofarenks değişiklikleri, tek taraflı servikal lenfadenopati, polimorfik döküntü ve ekstremite değișikleri bulgularından en az dördünün aynı anda veya hastalık seyri sırasında var olması ile konulur $(4,5,9)$. Hastalık için farkındalık arttıkça uzamış ateşi olup diğer klasik KH tanı kriterlerini karşılamayan hastalarda koroner arter tutulumunun olduğu görülmüştür ve atipik KH terimi kullanılmaya başlanılmıştır (10).

Atipik ve inkomplet $\mathrm{KH}$ terimleri aynı anlamda kullanılırken Newburger ve ark. (5) inkomplet KH terimini ateş yanında 3 veya daha az klinik bulgusu olan hastaları tanımlamak için, atipik $\mathrm{KH}$ teriminin ise klasik $\mathrm{KH}$ bulgularının yanında normalde sık görülmeyen ciddi tutulumları da olan (böbrek tutulumu gibi) olan hastaları tanımlamak için kullanılmasını önermişlerdir. Olgumuzda da uzamış ateş yanında on ikinci günde klasik KH bulguları gelişmiş ancak KH seyrinde çok beklenmeyen pnömoni tablosu gözlendiği için atipik KH tanısı konulmuştur.

KH seyri sırasında görülebilecek ek klinik bulgular arasında irritabilite, aseptik menenjit, akut iridosiklit, artrit, artralji, üretrit, ishal, kusma, safra kesesi hidropsu, BCG aşısı yerinde kızarıklık yer almaktadır $(5,6,11)$. Hastalığın akut döneminde öksürük ve rinore şeklinde üst solunum yolu tutulumu göreceli olarak sık görülür. Baker ve ark.'nın (6) çalışmasında 198 KH olgusunun \%19'unda rinore, \%28'inde öksürük saptanmıştır.
KH'da pnömoni şeklinde klinik bulgu veren akciğer tutulumu son derece nadir görülmektedir ve literatürde vaka sunumları şeklinde mevcuttur. Umezawa ve ark.'nın (12) çalışmasinda 129 olgunun akciğer grafileri incelenmiş ve \%14.7'sinde en sik retikülogranüler görünüm olmak üzere patoloji saptanmıştır. Picazo ve ark.'nın (13) 24 vakalık serilerinde 5 hastada akciğer grafisinde değişiklikler saptanmıştır. $\mathrm{KH}$ ve akciğer tutulumu ile ilgili Lee ve ark.'nın (14) çalışmasında 2003-2007 yılları arasında KH tanısı alan 358 olgunun 54'ünde (\%15) eş zamanlı pnömoni saptanmış ve 54 pnömoni vakasının 12'sinde etken olarak M.pneumoniae saptanmıştır. Olgumuzda bakılan M.pneumoniae IgM ve IgG negatif saptanmıştır.

$\mathrm{KH}$ ve akciğer tutulumu eş zamanlı olduğunda en önemli sorunun, mevcut akciğer bulgularının KH'nın akciğerlerde neden olduğu primer vaskülit nedeniyle mi oluştuğu yoksa olası süperantijen üretebilen bakteri nedenli akciğer enfeksiyonunun KH'nı mı tetiklediği ayırımını yapmak olduğunu düşünmekteyiz. Olgumuzda olduğu gibi literatürde de pnömoni tanısıyla antibiyotik tedavisi alan ancak klinik ve röntgen bulgularında düzelme olmayan $\mathrm{KH}$ olgularında IVIG tedavisi sonrası düzelme gözlenmiştir. Uziel ve ark. (15) iyileşmeyen pnömoni kliniği ile başlayan ve takiplerinde $\mathrm{KH}$ tanısı konulan iki olgu bildirmişlerdir ve akci$\breve{g}$ er tutulumunun vaskülite sekonder gelişen artmış damar geçirgenliğine bağlı olduğunu ileri sürmüşlerdir. Yavuz ve ark.'nın (16) sunduğu pnömoni ve drenaj gerektiren plevral efüzyonu olan ve antibiyotik tedavisine yanıt vermeyen 11 aylık olguda IVİG tedavisi sonrası klinik ve laboratuar bulgularında dramatik iyileşme gözlenmiştir. Olgumuzda da başlangıç bulguları olarak uzamış ateș ve akciğer bulguları mevcuttu. Beşinci günde pnömoni tanısı konulan olguda antibiyotik tedavisi ile düzelme olmamış ve on ikinci günde KH tanısı ile IVİG uygulanması sonrası klinik ve grafi bulgularında hızla düzelme gözlenmiştir. Olgumuzda akciğer tutulumunun KH'na ikincil gelişen vaskülit nedenli olduğu düşünülmüştür.

KH'da en önemli morbidite ve mortalite nedeni koroner arter tutulumudur ve tedavisiz olgularda \%20-25 oranında gözlenir. Koroner arter tutulumunu arttıran en önemli risk faktörleri geç tanı konulması ve tedavi verilmesi (10 günden sonra) ve İVİG tedavisi sonrası ateşin düşmemesidir $(5,9)$.

Olgunun hastanemize ilk gelişi olan ateşinin 9. gününde inkomplet $\mathrm{KH}$ düşünmemize rağmen ekokardiyografik inceleme normal saptandığı için IVIIG tedavisi vermeyi erteledik. 
Ancak 3 gün sonra tipik KH bulguları gelişen ve ekokardiyografide koroner arterlerde ektazi saptanan olgu, KH tedavisinde vurgulanan ilk 10 gün içinde tedavi vermenin önemini bize tekrar hatırlatmıştır.

Sonuç olarak, erken tanı ve tedavi ile koroner arter tutulumu engellenebileceği için uzamış ateşi olan, akciğer tutulum bulguları olup uygun antibiyotik tedavisine rağmen klinik, laboratuar ve radyolojik bulgularında düzelme olmayan olgularda $\mathrm{KH}$ ayırıcı tanıda düşünülmelidir.

\section{KAYNAKLAR}

1. Nakamura Y, Yanagawa H. The worldwide epidemiology of Kawasaki disease. Prog Pediatr Cardiol 2004;19:99-108

2. Kawasaki T. Pediatric acute mucocutaneous lymph node syndrome: clinical observation of 50 cases. Arerugi (Jpn J Allergy) 1967;16:178-222.

3. Yeung RS. Kawasaki disease: uptade on pathogenesis. Curr Opin Rheumatol 2010;22:551-60.

4. Ozen S, Ruperto N, Dillon MJ, Bagga A, Barron K, Davin JC, et al. EULAR/PreS endorsed consensus criteria for the classification of childhood vasculitides. Ann Rheum Dis 2006;65:936-41.

5. Newburger JW, Takahashi M, Gerber MA, Gewitz MH, Tani LY, Burns JC, et al. Diagnosis, treatment, and longterm management of Kawasaki disease: a statement for health professionals from the Committee on Rheumatic Fever, Endocarditis and Kawasaki Disease, Council on Cardiovascular Disease in the Young, American Heart Association. Circulation 2004;110:2747-71.

6. Baker AL, Lu M, Minich LL, Atz AM, Klein GL, Korsin $R$, et al. Associated symptoms in the ten days prior to diagnosis of Kawasaki disease. J Pediatr 2009;154:592-5.

7. Rowley AH, Wolinsky SM, Relman DA, Sambol SP, Sullivan J, Terai $M$, et al. Search for highly conserved viral and bacterial nucleic acid sequences corresponding to an etiologic agent of Kawasaki disease. Pediatr Res 1994;36:567-71.

8. Rowley AH. The etiology of Kawasaki disease: superantigen or conventional antigen?. Pediatr Infect Dis $J$ 1999;18:69-70.

9. Council on Cardiovascular Disease in the Young; Committee on Rheumatic Fever, Endocarditis, and Kawasaki Disease; American Heart Association. Diagnostic guidelines for Kawasaki disease. Circulation 2001;103:335-6.

10. Sonobe T, Kawasaki T. Atypical Kawasaki disease. Prog Clin Biol Res 1987;250:367-78.

11. Gong GW, McCrindle BW, Ching JC, Yeung RS. Arthritis presenting during the acute phase of Kawasaki disease. J Pediatr 2006;148(6):800-5.

12. Umezawa T, Saji T, Matsuo N, Odagiri K. Chest x-ray findings in the acute phase of Kawasaki disease. Pediatr Radiol 1989;20:48-51.

13. Picazo M, Fernandez-Mentes J, Fabrega R, Calatayud A, Vazquez G, Ros M. Radiologic findings in the lungs of patients with Kawasaki disease. Radiologia 2006;48(1):14-8.

14. Lee MN, Cha JH, Ahn HM, Yoo JH, Kim HS, Sohn S, et al. Mycoplasma pneumoniae infection in patients with Kawasaki disease. Korean J Pediatr 2011;54(3):123-7.

15. Uziel Y, Hashkes PJ, Kassem E, Gottesman G, Wolach B. 'Unresolving pneumonia" as the main manifestation of atypical Kawasaki disease. Arc Dis Child 2003; 88(10):940-2.

16. Yavuz T, Nisli K, Yllmaz C, Dindar A. Large pleural effusion necessitates tube drainage in a patient with Kawasaki disease. J Paediatr Child Health 2007;43(3):191-2. 